are about $2 \mathrm{~mm}$. and in those of $15^{\circ}$ are $3 \mathrm{~mm}$. If determination of meridian takes place according to the face of the clock, $10^{\circ}$ is equal to one-third, $15^{\circ}$ to one-half of an hour. In determinations based on estimation such mistakes may easily occur, and in themselves may make the success of the operation doubtful.

2. The localization on the fundus can be most exactly made with the aid of a perimeter because we determine the meridian and latitude in smaller units and thus lessen the possibility of faults occurring.

3. Besides being easy to manipulate, the proposed localizing perimeter makes it possible to project the meridian on to the eye and thus we can avoid faults connected with the transfer.

\title{
LITERATURE.
}

Clausen.-Ber. d. deutsch. Ophthal. Gesellsch., Vol. XLVIII, p. 63, 1931.

Colenbrander.-Arch. f. Ophthal., Vol. CXXVI, p. 424, 1931.

Comberg.-Ber. d. deutsch. Ophthal. Gesellsch., Vol. XLVIII, p. 322, 1931.

Bisher, J. H.-Zentrabl. f. Ophthal., Vol. XXVI, p. 811, 1931.

Fischer, F. P.-Klin. Monatsbl. f. Augenheilk., Vol. LXXXVII, p. 537, 1931.

Gonin.-Ber. d. deutsch. Ophthal. Gesellsch., Vol. XLVII, p. 46, 1929.

Guist.-Ber. d. deutsch. Ophthal. Gesellsch., Vol. XLVIII, p. 343, 1931.

Imre.-Ber. d. deutsch. Ophthal. Gesellsch., Vol. XLVIII, p. 321, 1931.

Klein.-Klin. Monatsbl. f. Augenheilk., Vol. LXXXVII, p. 537, 1931.

Lindner.-A rch. f. Ophthal., Vol. CXXIII, p. 233, 1930.

Luntz.-Zeitschr. f. Augenheilk., Vol. LXXIII, p 380, 1931.

Majewski.-Zentralbl.f. Ophthal., Vol. XXIV, p. 637, 1932.

Weve.-Klin. Monatsbl. f. Augenheilk., Vol. LXXXVII, p 145, 1931.

\section{A CASE OF CONGENITAL CATARACT SHOWING UNUSUAL FEATURES}

\author{
BY \\ D. J. WOOD \\ CAPE TOWN
}

A HEalthy and well grown Swahili boy was brought to me from the Athlone School for coloured children. There was nystagmus, and a dense white opacity in each pupil which reduced his vision to mere light and dark.

The iris acted normally, but on dilating the pupils a very remarkable appearance presented itself which I have tried to depict. The drawing was difficult and tedious owing to the nystagmus, the nervousness of the patient, and my inability to speak his language. The lights and shadows are exaggerated by the brilliant light of the slit lamp, and I have taken some liberties with the irides as they were normal and not associated with the actual abnormalities.

In the centre in each . eye was a very dense circle of capsular opacity, with a yellowish raised epicapsular spot, and several smaller specks, remains of lens matter. These were more numerous in the 
Congenital Cataract

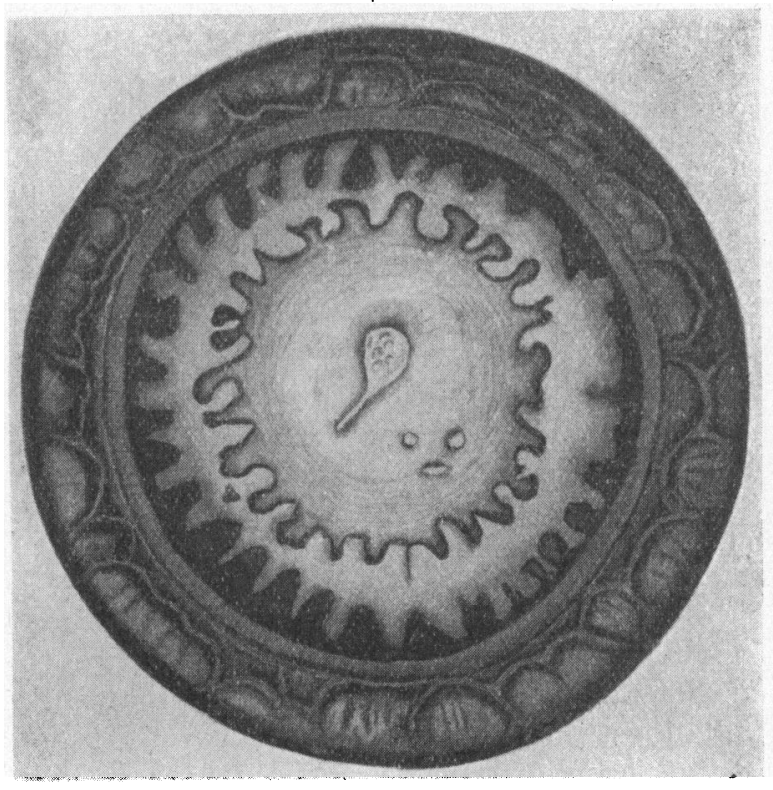

LEFT EYE

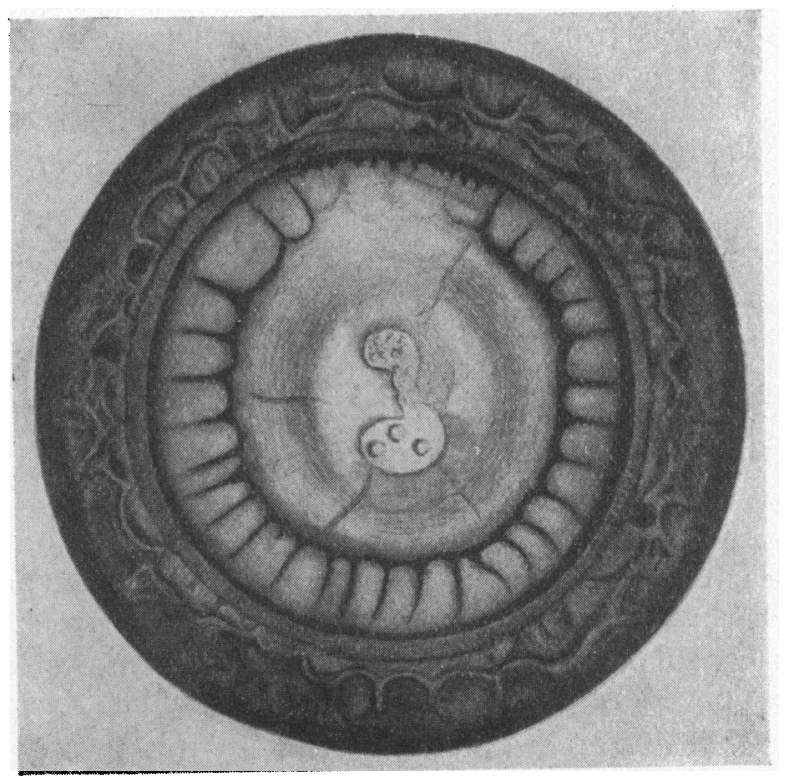

Right EyE 
left eye. The central dense part was marked by concentric lines, rather bluish in the right eye, and giving the tissue an appearance reminiscent of tendon.

The curious part was the presence round this central opacity of a flat slate-coloured band, notched at its inner margin, and furrowed on its surface. The markings were so dark that at first one thought them due to actual pigment, but more careful examination showed that they were thinner parts through which the dark interior was dimly seen. The appearance in the right eye indicated that the markings were due to the radial ridges of the iris uvea. The left was more irregular but also suggestive.

It was evident that the lens was largely absent and was represented only by capsule, but why the centre was dense, and the periphery thin and stamped by the impress of the uvea was not clear. The general appearance was similar in the two eyes, and postulated a common cause.

As there was a definite border between the dense central part and the thinner outside band I attempted to separate them with a discission needle, and found this quite easy, so that one left a round disc of capsule loose in the anterior chamber. This was removed the following week and a round clear space was left. Thereafter the drawing of the left eye was made and the same treatment followed.

The round portion of the capsule, $5 \mathrm{~mm}$. in diameter, was examined under the microscope and showed an anterior surface marked by digitate wrinkles outlined by very fine round pigment atoms, and a posterior surface with concentric wrinkles, and oval nuclei lying in lines corresponding to them. No nuclei belonging to the anterior capsule were visible. What were seen appeared to represent the only remains of the lens. They stained feebly.

The fundus was normal and the vitreous clear. Though there was uveal pigment in very fine particles on the anterior surface of the capsule there was no trace of iritis.

The boy sees well with his glasses, but so far is illiterate.

Many years ago I saw a patient who had been struck on his eye by a non-penetrating pellet. His lens presented a condition faintly like the present case. The uveal marking of the iris and of the edge of his pupil were indicated by lines resembling what might be made by a soft lead pencil. It was, however, only a ghost compared with the present case.

It is clear that the cause of the trouble is prenatal, but it is not so clear at what time it occurred nor what was the mechanism.

The epicapsular deposits seem to indicate that the lens capsule had been opened in each eye, but that there had been no intrauterine iritis seems also certain.

May one suppose that the thinner part of the lens capsule in the centre was so far abnormal that it gave way as the lens grew, and 
allowed the aqueous to penetrate and ultimately dissolve the whole lens substance? The swelling of the lens during the earlier stages might bring the lens capsule against the iris, with the result that the pattern of its uvea remained as a permanent appearance. It seems a possible explanation.

\title{
A CLINICAL NOTE ON GLAUCOMA
}

\author{
BY \\ E. E. Maddox \\ BOURNEMOUTH
}

THE following simple addition to our ordinary measures for reducing the tension in most cases of glaucoma seems worth communicating.

About five years ago I was much interested to discover that high frequency currents had the effect of almost immediately lowering the tension in nearly all moderately hypertense eyes.

In one case only during these years has an untoward sequel resulted. The patient had toxic cyclitis with secondary glaucoma, and the treatment was followed by a temporary increase of hardness and pain. It was this case that made me delay publication till further experience should prove the method safe enough to recommend. Caution, therefore, should be observed with inflamed eyes. With very hard and strangulated eyes the effect may be nil.

The application need not be longer than from one to four minutes, and although the effect is more or less transitory, I find that in most cases, repeated applications do good in the long run. This indeed is what we might expect, for a temporary reduction of tension must allow the oppressed structures a breathing space in which to recover themselves from the continuous pressure, thus allowing a flushing with fresh blood and consequent increase of nourishment.

Until recently I have applied the current, either directly or through the operator's fingers, to the eyeball itself through the closed lids ; but now find it makes little difference if the application is made instead against the temporal margin of the orbit. In order not to startle the patient, the current should not be turned on until contact has been made with the skin, as otherwise slight sparking is caused. In any case the patient may be assured that there will be no shock.

The lowering of the general blood pressure by ordinary high frequency currents applied to the body has long been a matter of common knowledge, but the local effect of these weak currents on glaucoma does not appear to have attracted attention, and will, I hope, prove a useful addition to our ophthalmic armamentarium. 